\title{
Between Ego Documents and Anti-Catholic Propaganda: Printed Revocation Sermons in Seventeenth-Century Lutheran Germany
}

\author{
Martin Christ
}

In 1670, the revocation sermon (Revocationspredigt) of Georg Friedrich Habel came off the printing press in Leipzig. The text was based on a sermon Habel delivered on 4 January 1670, making it not only a revocation sermon, but also a New Years' sermon (Neues Jahr / oder Revocation-Predigt).*,1 In it, he explained and justified his decision to leave behind the Catholic Church and to become a Lutheran. The sermon was reprinted six years after its first publication in a slightly altered version, with minor changes in the title and without a dedication. Apparently there was enough demand to merit printing this second version. ${ }^{2}$ Johann Georg, also called Georgi, one of the most prolific printers in Leipzig at the time, printed both texts. So far as we know, this was the only work by Habel that was printed, and little is known about him aside from the information in his sermon.

Habel's sermon had a plain title page, without any illustrations, border decorations or other visual markers (see figure 17.1). The text was divided into several sections, and key features of the text, like the title of the sermon and Habel's name, were printed in a larger typeface, immediately drawing the reader's eye to them. The title stressed that Habel had left Popery behind and found his way to the only true church - the Lutheran one. The sermon is dedicated to the pastors and consistory of Dresden, who were in charge of ensuring the orthodoxy of Saxon Lutheranism. They also would have been responsible for testing Habel when he first expressed his desire to convert to Lutheranism.

* This chapter was written in the Centre for Advanced Studies 'Urbanity and Religion: Reciprocal Formations', based at the Max-Weber-Centre for Advanced Cultural and Social Studies of the University of Erfurt. The group is funded by the Deutsche Forschungsgemeinschaft (DFG, German Research Foundation) - FOR 2779.

1 Andreas Franciscus Habel, Neues Jahr/ Oder Revocation-Predigt: In welcher wohlgewogene Motiven oder Ursachen an Tag gegeben werden; warumb der Wiederruffende seinen alten Menschen des Papistischen Irrthumbs/ oder irrenden Pabstthumbs ausgezogen/ und sich im Geist der allein seligmachenden Evangelischen Religion verneuert hat (Leipzig: Georg, 1670).

2 Andreas Franciscus Habel, Neues Jahr/Oder Revocation-Predigt (Leipzig: Georg, 1676). 


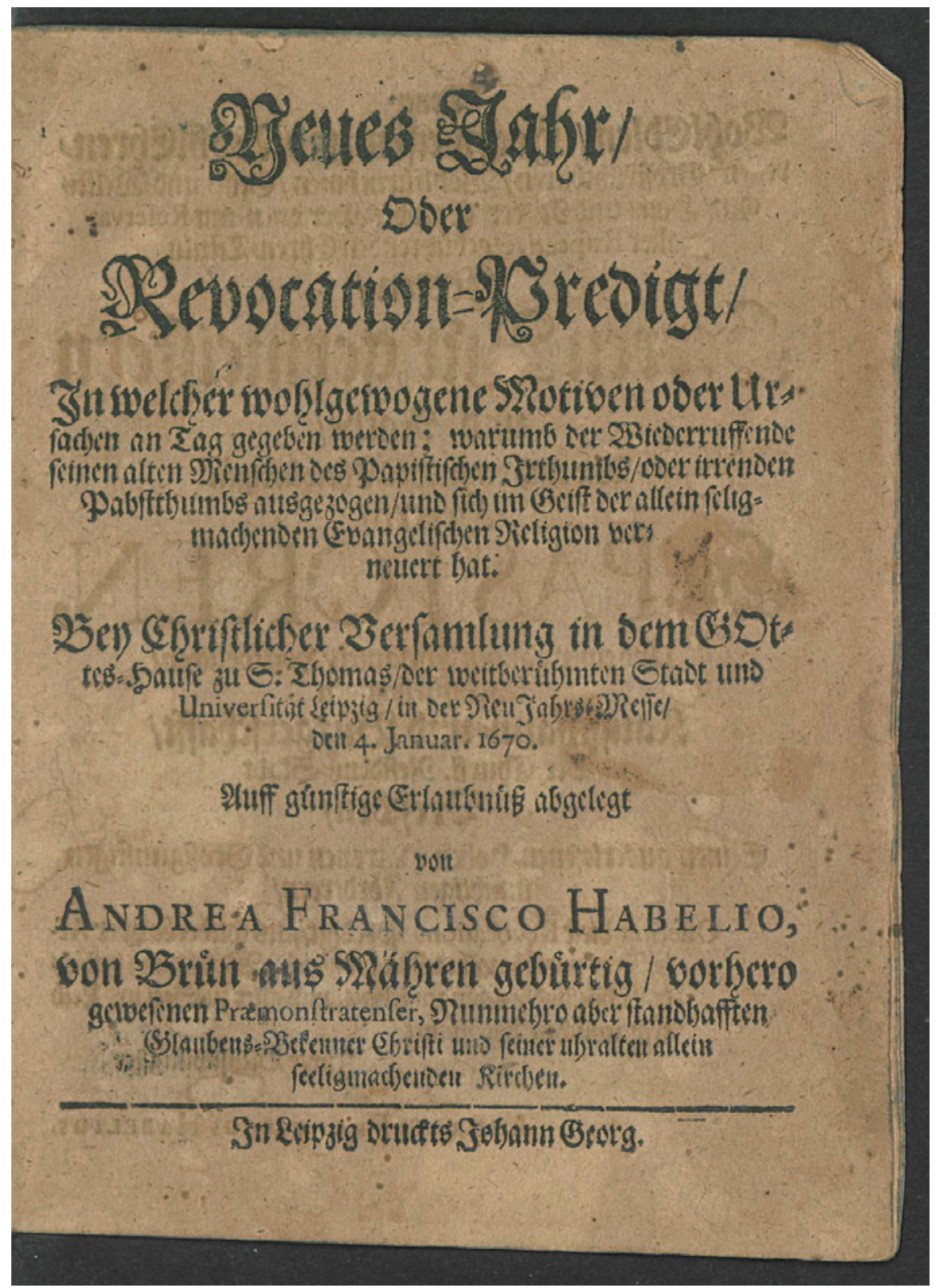

FIgURE 17.1 Title page of Andreas Franziskus Habel's Neues Jahr/Oder Revocation-Predigt (Leipzig: Johann Georg, 1670) 
They might even have been able to find a post for him, which was a big concern for recent converts, as they could no longer rely on their monastic infrastructure for board, money and food. ${ }^{3}$

In the sermon, Habel revoked his Catholic beliefs and attacked the Catholic sacraments and other key features of Catholicism. The sermon ends with a formal revocation, which Habel would have read out from the chancel for all those gathered in the church to hear. ${ }^{4} \mathrm{He}$ stressed the errors of his ways once again, identified himself as a former Catholic who had experienced the errors of Catholicism first hand, and promised to adhere to key writings of the Lutheran faith, like the Formula of Concord. Habel was part of a group of more than one hundred men who justified their conversion in this way.

Over the course of the seventeenth century, revocation sermons became a popular genre of writing for men who had left behind their Catholic beliefs and wanted to show their Lutheran credentials. While the sermons followed the same patterns when it came to their layout, attacks on the Pope or challenge to monasticism, they were also deeply personal ego-documents connected to an individual convert. The sermons were rarely longer than thirty pages and usually in quarto size. The first revocation sermon was delivered around 1600 , the last one in the 1730s, making the lifespan of the genre coincide with the period of German history defined by political instability before and during the Thirty Years' War, and subsequent efforts to rebuild the country. ${ }^{5}$ It transgresses the boundary of 1648 as a watershed moment, and instead emphasises the continuation of religious tensions after the war and throughout the seventeenth century.

The emergence of the revocation sermon was probably connected to broader political developments. The Regensburg Colloquy in 1601 was one of the last major meetings between Catholics and Lutherans, when they attempted to convince each other of their viewpoints and unify Western Christendom. The breakdown of these talks coincided with the first revocation sermons. With the permanent fragmentation of Western Christendom came the revocation sermons, which implicitly recognised these hardened boundaries. The outbreak of the Thirty Years' War resulted in further conflicts and polemical exchanges between Lutherans and Catholics. With this warfare came the displacement of large numbers of people, which also influenced conversions. These could be forced, when towns were conquered by European powers, or voluntary,

3 See Alexander Schunka, Gäste, die bleiben. Zuwanderer in Kursachsen und der Oberlausitz im 17. und frühen 18. Jahrhundert (Hamburg: LIT Verlag, 2006).

4 Habel, Neues Jahr/Oder Revocation-Predigt (1670), unpaginated.

5 On the Thirty Years War more broadly, see Peter H. Wilson, Europe's Tragedy: A New History of the Thirty Years War (London: Penguin, 2010). 
when people fled and converted in order to be fully integrated into a new society. But, even after the Thirty Years' War, revocation sermons continued to be printed, particularly in the 166os. Gradually, conversions became less contentious, resulting in fewer controversies revolving around conversions in the eighteenth century.

Conversions were a complex process and have become a significant area of research in the past fifteen years. ${ }^{6}$ David Luebke and others have shown, for example, that conversions were closely tied to political, and not just religious considerations. ${ }^{7}$ Alexander Schunka has explored the dynamics between conversion and migration, and argued that a broad range of motives contributed to the decision to change confession. ${ }^{8}$ Other scholars have explored the importance of conversion within marriages, while further studies have shed light on the conversion of territorial rulers and princes and asked how they interacted with their subjects after the conversion. ${ }^{9}$ All these studies show that conversions in early modern Europe are a valuable field of inquiry.

This chapter adds to this research by considering a particular kind of conversion narrative: the revocation sermon..$^{10}$ The research draws on around one hundred such conversion sermons, which were delivered in German towns between the beginning of the seventeenth and the middle of the eighteenth centuries. Most of the sermons were printed soon after the converts proclaimed their conversion in major Lutheran churches. These sermons are particularly valuable because they focus on conversions to Lutheranism, a field

6 See, for example, Ute Lotz-Heumann, Matthias Pohlig and Jan-Friedrich Missfelder (eds.), Konversion und Konfession in der Frühen Neuzeit (Gütersloh: Gütersloher Verlagshaus, 2007); Kim Siebenhüner and Monica Juneja (eds.), Religious Conversion in Medieval and Early Modern Societies, special issue of The Medieval History Journal 12 (2009); Kim Siebenhüner, 'Glaubenswechsel in der Frühen Neuzeit. Chancen und Tendenzen einer historischen Konversionsforschung', Zeitschrift für Historische Forschung, 34 (2007), pp. 243-272.

7 David M. Luebke etc. (eds.) Conversion and the Politics of Religion in Early Modern Germany (New York/ Oxford: Berghahn, 2012).

8 Schunka, Gäste, die bleiben.

$9 \quad$ David M. Luebke and Mary Lindemann (eds.), Mixed Matches. Transgressive Unions in Germany from the Reformation to the Enlightenment (New York/Oxford: Berghahn, 2014); Eric-Oliver Mader, 'Fürstenkonversionen zum Katholizismus in Mitteleuropa im 17. Jahrhundert. Ein systematischer Ansatz in fallorientierter Perspektive', Zeitschrift für Historische Forschung, 3 (2007), pp. 403-440.

10 For a linguistic analysis, see Sarah Rütter, Konstruktion von Bekenntnisidentität in Konversionsschriften der Frühen Neuzeit (Berlin: LIT Verlag, 2014). There are some notable exceptions, for example Duane J. Corpis, Crossing the Boundaries of Belief: Geographies of Religious Conversion in Southern Germany, 1648-1800 (Charlottesville, VA: University of Virginia Press, 2014). 
which has received less scholarly attention than other kinds of conversions. ${ }^{11}$ Broadly speaking, the converts justified and defended their decision to abandon the Catholic Church in these sermons. At the same time, they flattered important Lutheran princes and councilors, hoping to receive financial and logistical support.

A wide range of former Catholic clerics delivered revocation sermons. Most of them were former members of orders, and many of them from territories bordering on Saxony or other Lutheran territories. Bohemian monks, for example, came to Saxony and delivered their revocation sermons there. The list of converts spans all the major early modern orders, including Franciscans, Capuchins, Augustinians and Jesuits. The conversion of these men, some of them high-ranking in the Catholic hierarchy, were a boon for the Lutherans, who could claim a victory over the Catholics during a time when confessional tensions were high.

The converts wanted to prove that they had seen the error of their ways in these sermons. ${ }^{12}$ Having their revocation sermons printed was a particularly appealing way for the recently converted men to show their piety, and was an opportunity to emphasise that the conversions were not linked to financial or political benefits, but rather inspired by the conviction that Lutheranism was the true religion. If anything, the converts frequently claimed in their sermons that the conversion led to a worsening of their financial situation, meaning that the only reason for their change of faith was theological. By harnessing the power of print, these revocation sermons could go beyond the people immediately involved in the conversion, as the printing of the sermon significantly increased its reach, providing an opportunity for the converts to show themselves as true Lutherans.

\section{The Development of the Revocation Sermon}

The first revocation sermons from the early seventeenth century proved to be crucial for the development of the genre. ${ }^{13}$ Prefaces describe the process that a former Catholic cleric who wanted to convert had to undergo. He had to express his desire to convert, and, in a talk with the Lutheran theology faculty, explain his reasons for doing so. If the faculty was convinced, they gave him

\footnotetext{
11 See for example, Luebke etc. (eds.), Conversion and the Politics of Religion.

12 Schunka, Gäste, die bleiben, p. 335 .

13 For example, Gottfried Rabe, Christliche Revocation Predigt. Des Ehrwirdigen Godefridi Raben/Gewesenen Augustiner Münchs/ und Predigers zu Prage bey S. Thomas auff der kleinen Seiten (Wittenberg: Lehmann, 16o1), USTC 2104295.
} 
their blessings. The public act of conversion was a crucial aspect of the convert's journey and helped to legitimise his decision. The spread of conversion narratives in print was therefore an important aspect of a change in confession. The early sermons were templates for later converts, who used revocation sermons and employed a similar language and layout to the first individuals operating within this genre.

The term Revocationspredigt only appeared in the early seventeenth century. Before that, other clerics had justified their reasons for taking up a new faith in print, but they did not call their sermons a Revocationspredigt. Importantly, these were converts to Catholicism, like Caspar Franck in 1568 and Sebastian Flasch in $1576 .{ }^{14}$ Both of them explained why they had left the 'Lutheran sect' to join the 'general Christian and Roman church'. In these sermons, the authors argued that salvation could only be found in the Catholic Church. Because the early converts to Lutheranism coined, or at least popularised the term revocation sermon, the term was mainly used by Lutherans. After these early printed sermons, including ones endorsed by the University of Wittenberg, Lutherans used called their sermons Revocationspredigten and emphasised it by printing it in a large typeface.

The sermons were initially spoken and performed as part of a Lutheran service and integrated into Lutheran worship. Gottfried Rabe, for instance, delivered his sermon on Misericordias, the Second Sunday after Easter. ${ }^{15}$ Traditionally, the sermon on that Sunday centred on the topic of Christ as shepherd, which is exactly what Rabe preached on. Another example is Georg Friedrich Habel's sermon, with which this chapter started, doubled as a New Year's sermon. ${ }^{16}$ Some of the converts explicitly referred to listeners, emphasising the spoken nature of the sermons. ${ }^{17}$ In some sermons, other liturgical features like prayers or hymns are also mentioned, and show clearly how the convert was integrated into the Lutheran community. Printing these features was important for the converts, as they suggested that the converts were not only truly Lutheran, but that they could even be the central part of a Lutheran liturgy. It was essential that converts showed their integration into the liturgy, because they received their education in a Catholic context and for many

14 Caspar Franck, Dilucida expositio justissimarum caussarum (Ingolstadt: Weißenhorn, 1568), not recorded in ustc; Rütter, Konstruktion von Bekenntnisidentität, pp. 143-145. See also Ute Mennecke-Haustein, 'Konversionen', in Wolfgang Reinhard and Heinz Schilling (eds.), Die Katholische Konfessionalisierung (Gütersloh: Gütersloher Verlags-Haus, 1993), pp. 242-258.

15 Rabe, Christliche Revocation Predigt, title page.

16 Habel, Neues Jahr/Oder Revocation-Predigt, title page.

17 Flaskamp, Den eintzigen, festen und unbeweglichen Grund Des Glaubens, p. 3. 
decades had administered communions in one kind, lived a celibate life, and adhered to Catholic teachings.

Revocation sermons were not as numerous as other typically Lutheran publications, most notably the funeral sermon. Research on the funeral sermon has pointed to how Lutherans monopolised this genre of writing, and a similar process occurred with revocation sermons, though on a smaller scale. Like funeral sermons, the revocation sermon can be read in multiple ways: as a confession of faith and victory for Lutheranism over Catholicism, an opportunity to praise Lutheran dignitaries, and for them to emphasise their power or as ego-documents which relate personal biographies. ${ }^{18}$

It is notoriously difficult to trace the influence of printed works, and revocation sermons are no exception. There are some indications, like passing remarks in other works, which suggest that they were read. In terms of printers and collectors, the evidence is variable. Some of the revocation sermons went through as many as seven editions, and were reprinted on presses across the Holy Roman Empire. ${ }^{19}$ These sermons also found their way into a range of libraries and survive in multiple copies. There are also revocation sermons for which there is only a single surviving copy, which may indicate sustained use. However, there are also some sermons that were only printed in one edition and I have not been able to find any reference to them in other works. Whether the sermons circulated widely or not seems to have depended on specific circumstances, for instance the position the convert held before his conversion, where and when he converted or whether there were any Catholic responses. ${ }^{20}$

Throughout the sermons, the authors attacked Catholicism and stressed in turn the Lutherans' righteousness. The description of the Pope as the Antichrist was a standard Lutheran trope, which became one of the defining features of early modern Lutheranism. By attacking Catholicism in this way, the converts followed long-established patterns that Martin Luther himself had used. Already in the early to mid-sixteenth century, the sacraments, the power of indulgences, saints, and pilgrimages, as well as papal infallibility were central points of attack. The authors of the revocation sermons took up these commonplace criticisms, positioning themselves in a long tradition of Lutheran

18 On funeral sermons, see, for example, Cornelia Niekus Moore, 'Mitteldeutsche Leichenpredigten als Spiegel des Zeitgeschehens', in Philip Hahn, Kathrin Paasch and Luise Schorn-Schütte (eds.), Der Politik die Leviten lesen. Politikvon der Kanzel in Thüringen und Sachsen, 1550-1675 (Gotha: Forschungsbibliothek Gotha, 2011), pp. 48-58.

19 For an overview, see the sermons printed in the German lands in VD17 and VD18, which list many of the revocation sermons and the number of editions. The library catalogue of the Saxon and university library (SLUB) references further revocation sermons. Revocation sermons which led to Catholic responses include the one by Gottfried Rabe, Wenceslaus Altwasser and Ferdinand Franz Weinberger. 
polemicists, which started with Luther himself. In the words of Alexander Schunka, 'revocation sermons had to be written according to certain rules and they corresponded closely with the legitimisation of confessions in general and the legitimacy of Lutheranism as a confession'. ${ }^{21}$

Converts attacked Jesuits particularly fervently. Antonius Flaskamp wrote that the Pope's 'loyal guards, the Jesuits, think they are not bound to the church fathers'.22 Martin Schimschalck was even more explicit, writing that 'I know well that the turbulent Jesuits are the greatest enemies of the Christian faith, who with shouting and blasphemy topple everything they do not know.' ${ }^{23}$ With their teachings, the 'crazy and senseless Jesuits create a fog in front of the eyes of the common people', telling them that they were not allowed to drink wine in the Eucharist. ${ }^{24}$ The former Catholics hoped to discredit one of the most important features of early modern Catholicism and, at the same time, challenged one of the orders that was crucial in converting men and women to Catholicism.

The revocation sermons did not only have this anti-Catholic dimension; they also praised Lutheranism as the 'true religion'. One particularly common trope was that of papal darkness, which was superseded by the light of Lutheranism.' ${ }^{25}$ In some of the sermons, the converts also made very specific

21 Schunka, Gäste, die bleiben, p. 337: 'Revokationsschriften hatten also nach bestimmten Spielregeln abgefaßt zu warden, und diese korrespondierten aufs engste mit der Legitimation einer Konversion überhaupt und mit der Legitimität des Luthertums als Konfession'.

22 Augustinus Flaskamp, Den eintzigen, festen und unbeweglichen Grund Des Glaubens, Zeigte In einer Christlichen Revocations-Predigt Nach Anleitung des am 2ten Advents-Sonntag gewöhnlichen Evangelii aus dem Luc. 21. Anno 1726. In der Hoff- und Stadt-Kirche der Neu-Stadt Hannover Bey Volckreicher Versammlung und grossem Gedränge vieler Zuhörer Augustinus Flaskamp, Vor Zeiten Prediger-Ordens viele Jahren durch gewesener Prediger (s.l.: s.n., 1727), p. 21.

23 Martin Schimschalck, Kurtze Revocations Predigt / Jn welcher Dem abgöttischen Pabsthum un $[d]$ seinem gantzen verführischen Anhang offentlich abgesaget / hingegen dem Eckstein der wahren Evangelischen Lehr und Religion / welcher ist Christus Jesus / gepriesen unnd erklähret wird (Leipzig: Guirin Bauch, 1658): 'Jch weis wol was die unruhigen Jesuiten / die allerärgsten Feinde des Christlichen Glaubens / welche mit ihrem schreyen und lästern alles was sie nicht wissen / über einen hauffen zu stossen'.

24 Schimschalck, Kurtze Revocations Predigt, 'Aber damit die tollen und unsinnigen Jesuiten / dem gemeinen Mann / einen Dunst vor die Augen machen / das sie solches nicht verstehen sollen / sprechen / das der Layen gar viel seyn die keinen Wein trincken / fürs ander / das an etlichen Orten keiner zu bekommen were / fürs dritte das offtermals die Bauren grosse Schweitzer bärte hetten / und gar leichtlich etwas darvon abtrieffeten / woran man grosse Sünde thete / were derowegen besser / das man das Kelch geben unterwegen liesse'; 'schlechte Argumente'.

25 For example, Wenceslaus Altwasser, Ungegründetes Pabstthum / Samt einer gründlichen Erweisung seines wohlerwogenen billigen Abweichens von dem Irrlicht des Pabstthums 
references to important Lutheran tracts, like the Augsburg confession or Luther's catechism. ${ }^{26}$ In this way, they hoped to show their own Lutheran credentials, and others could uphold them as examples of a good Lutheran.

\section{The Structure of the Revocation Sermons}

The overall structure of the sermon was clearly defined by the middle of the seventeenth century, and many of the sermons followed a similar pattern, which included a preface or dedication followed by an autobiographical part, a quote from Scripture, denunciation of Catholicism, including references to the Pope as Antichrist, the Eucharist, saints and pilgrimages and, finally, the formal revocation. As Sarah Horstkamp has shown regarding the conversions of Johann Wilhelm Freymüller and Thomas Strobel, converts copied from each other, suggesting that one conversion could influence how another person framed their turning towards Lutheranism. ${ }^{27}$ Johann Samson's sermon, too, copied from the revocation sermon of Gottfried Rabe verbatim, including the phrase 'Furthermore, I denounce and condemn the malign Popery, including all other sects and groups that fight and argue against God and his word'. ${ }^{28}$ The circulation of the printed sermons meant that converts influenced each other's language, rhetorical strategies, and figures of speech.

Most sermons contained a formulaic ending, in which the convert renounced his previous beliefs. In many ways, the whole sermon moved towards this climactic final passage in which the reasons for the conversion and corrupt nature of the Catholic Church were emphasised once more. For example, Christoph Grosspietsch's 1608 sermon, printed in Jena, ended with the words:

[in front of this] large, Christian gathering (Christlichen Volckreichen Versamblung), I confirm that I was not forced, urged or instructed to make

zu dem helleuchtenden Evangelischen Glaubens-Licht der wahren Lutherischen Kirchen Augspurgischer Confession (Jena: Johann Risio, s.d.).

26 Habel, Neues Jahr/Oder Revocation-Predigt.

27 Sarah Horstkamp, 'Konversionsschriften zwischen Muster und Variation - zwei protestantische Fallbeispiele', in Jürgen Macha, Anna Maria Balbach and Sarah Horstkamp (eds.), Konfession und Sprache in der Frühen Neuzeit: interdisziplinäre Perspektiven (Münster: Waxman Verlag, 2012), pp. 9o-97.

28 Johannes Samson, Illuminatus Samson, Das ist: Erleuchtungs - oder Revocations-Predigt: Nach dem der Author Johannes Samson, gewesenen Franciscaner Münch ... mit dem (Titul) Herrn Doctore Anania Webero controvertiret ... Gehalten Den ersten Sontag in der Fasten/ welcher war der erste Martii lauffenden Jahrs 1648 (Frankfurt an der Oder: Koch, 1648), USTC 2103159 . 
this revocation in front of the congregation of Christ, but I make it voluntarily, out of my own love of the truth I recognised. For this reason alone, I reject with my whole heart and whole soul, with all my conscience and all my powers one and all papal cruelties, whatever their name is. And I recognise the Roman Pope as an evil person (Menschen der Bosheit) and a child of corruption, who Daniel the Prophet and Paul the apostle predicted. Furthermore, I recognise that his teachings are against Christ, devilish, yes that they are the poison of the Whore of Babylon [mentioned] in Revelations.... I profess the Augsburg Confession, as it was presented to the powerful Emperor Charles $\mathrm{V}$ in 1530 .... In future, I will work all the harder and avidly to show the truth and will endeavor to collect it and spread it. The Holy Spirit may confirm and strengthen this through his charisma, mercy and gifts in me through Jesus Christ our lord and savior in eternity. Amen. ${ }^{29}$

This kind of clear rejection and summary of important objections to Catholicism would have been the formal end to the conversion process, and the convert could then become a part of the Lutheran church.

29 Christoph Grosspietsch, Revocation Predigt, Am H. Pfingstdinstag, im Jahr 1608. In der Pfarrkirchen zu Jehna gehalten (Jena: Lippold, 1608), usTC 2053776, pp. 45-47:'dieser ansehlichen Christlichen Volckreichen Versamblung / das ich diesen öffentlichen Wiederruff vor der gantzen Gemeidne Christi / nicht gewzungen / gedrungen / oder auffgetragen / sondern freywillig aus einiger Liebe der erkandten Warheit hiemit verichte. Aus solcher allein verwerffe ich aus ganzem Hertzen / aus gantzer Seelen / aus gantzem Gemüht / und aus allen meinen Kräfften / alle und jede Bäpstische Grewel / mit was Namen die mögen genennet werden. Und erkenne den Römischen Bapst vor den Menschn der Bosheit / und das Kind des Verderbens / von dem Daniel der Prophet / und Paulus der Apostel geweissaget. Item ich erkenne auch / das seine Lehr sey Antichristisch / Teuffelisch / ja das Gifft der Babylonischen Huren / in der Offenbarung. Welche ich hiemit verwirff / verdam[m]e / verfluche und anathematizire / ja dero anathema maranatha imprecire. Hergegen steige ich frewdig und frolockend mit Zachaeo vom Feigenbaum / nimb frölich auff Christum in das Haus meines Herzens / das er dem Heil unnd alle Wolfahrt lasse wiederfahren. Ich nim jhn auff / wie er sich in den Prophetischen / apostolischen / Schrifften offenbahret hat. Bekenne mich auch zur unverfälschten Augspurgischen Confession / wie sie dem Grosmechtigen Keyser Carolo V. im Jahr 1530 praesentiret worden. Jch nehme auch an / alles was zu Erklärung derer in Formula concordiae begriffen. Jch stehe auch mit dem Zachaeo zu Christo sprechende / Herr so ich jemand betrogen hab / gieb ich es vierfältig wieder. Das ist: Hab ich in verganenen dreyzehn Jahren durch meine PRedigtenm die Herde Christi verfolget / So will ich ins künfftige desto fleissiger / embsiger und eifferiger die Warheit / deren fürzutragen / unnd durch solche sie zu samlen mich bemühen und befleissen. Welches der H. Geist durch seine Charismata Gnaden unnd Gaben in mir bestetigen und bekräfftigen wölle / durch Christum Jesum unsern Herrn und HEyland hochgelobet in Ewigkeit / AMEN. ENDE'. 
The structure of the revocation sermon was so clearly defined that, in 1726, Augustinus Flaskamp apologised in the preface to his printed sermon that he had not stuck to this structure when he first delivered it, but, now that it appeared in print, he was able to do so. ${ }^{30}$ Most of the sermons did not contain woodcut illustrations, though there are some exceptions, like some editions of Gottfried Rabe's sermon. Additionally, printer's marks had a prominent place in some of the sermons, for instance in that of Franciscus Albanus, which contains the printer's mark of the printer Samuel Seelfisch, showing Samuel anointing David. ${ }^{31}$ The woodcuts were usually standard biblical motifs, like Christ protecting his sheep. Only rarely did the sermons contain a depiction of the convert himself, as was the case with Johann Ludwig Niclasi. ${ }^{32}$

The revocation sermons also followed an increasingly unified pattern in terms of their layout. The title page of the sermons usually contained the convert's name, a description of the sermon and in many cases the location and date of the sermon. ${ }^{33}$ While some earlier revocation sermons contained the phrase revocation sermon buried somewhere in a long title, later examples started with the term, suggesting that, as the genre developed, it became more recognisable.

The revocation sermons were printed in a variety of towns, but printing presses in Saxony produced the greatest number of editions. Partly, this was because many of the sermons were delivered in important Saxon churches in Wittenberg, Dresden or Leipzig. The Saxon dominance in revocation sermons was also connected to a longer tradition of Lutheranism in that territory. By the seventeenth century, when most conversions took place, Saxony was already well established as an important Lutheran territory as well as a central European print centre.

However, it was not in the political centre of Dresden that most revocation sermons were delivered and printed, but rather in Wittenberg, where Luther had been a professor and lived most of his life. As Andrew Pettegree has shown,

$30 \quad$ Augustinus Flaskamp, Den eintzigen, festen und unbeweglichen Grund Des Glaubens (s.l.: s.n., 1727), unpaginated.

31 Franciscus Albanus, Francisci Albani Vangionis, SS. Theol. D. Gewesenen Pfarrherrns der Freyen Königlichen Bergstadt in Sanct JoachimsThal/ \&cc. Päbstische Anatomia : Darinnen Nach Ordnung der Eusserlichen Glieder des Pabsts/ das Römische Wesen/wie es heutiges tages darmit eine beschaffenheit hat/ beschrieben wird (Wittenberg: Seelfisch, 1636), USTC 2022620 .

32 Joh. Ludwig Niclaßi, Wohlverdientes Ehren-Gedächtnüs Dem Weyland Hoch-Ehrwürdigen und Hochgelahrten Herrn Herrn Joh. Ludwig Niclaßi, hochmeritirt- und wegen seiner sonderbahren Gaben sehr beliebt-gewesenen zweyten Stadt-Pfarrer in hiesiger Hoch-Fürstl. Residenz Darmstadt (Darmstadt: Forter, 1730).

For example in Schimschalck, Kurtze Revocations Predigt. 
Luther was instrumental in establishing the print industry in Wittenberg, and the converts benefitted from it. ${ }^{34}$ After Wittenberg, Leipzig was the second most important centre for the printing of revocation sermons. Many of the print workshops were connected to Lutheran rulers. For example, Tübingen, where some sermons were printed, was the main university in the Lutheran Duchy of Württemberg. ${ }^{35}$ Smaller presses in places like Olsse in Silesia or Wolfenbüttel also printed some of the sermons. ${ }^{36}$ Wolfenbüttel in the North West of the Holy Roman Empire was a territory that had turned Lutheran in 1568, and, with the University of Helmstedt, it possessed a significant presence of Lutheran theologians and professors. ${ }^{37}$ The printers who published the sermons also point to other Lutheran institutions that promoted the conversions by printing them. Johann Ulrich von Baumgarten's revocation sermon was printed by Herman Brauer in Bremen in 1686. Brauer was also the printer of the regionally significant Lutheran town school, which he advertises on the title page ('des Löbl. Gymn. Buchd.'). ${ }^{38}$

Another feature that many of these towns share is that they had important Lutheran universities. Lutheran theologians had to test a person who came to their territory, and assess whether the newcomers wanted to convert for reasons of their faith and 'conscience' (Gewissen) or for more practical reasons, like an improvement of the living conditions. The theologians questioned the potential converts, and, in some territories, this led to the establishment of separate bodies whose whole purpose was the interrogation and catechising of the converts. In Saxony, there was even talk of separate housing for the newly arrived converts. ${ }^{39}$ The printing of the revocation sermons enabled the converts not only to legitimise their conversions, but also to spread the news of their change of confession. By personalising their sermons, the converts made

34 Andrew Pettegree, Brand Luther: How an Unheralded Monk Turned His Small Town into a Center of Publishing, Made Himself the Most Famous Man in Europe - and Started the Protestant Reformation (London: Penguin, 2016).

35 See Richard Kirwan, 'The Conversion of Jacob Reihing: Academic Controversy and the Professorial Ideal in Confessional Germany', German History, 36 (2017), pp. 1-20.

36 Wenceslaus Altwasser, Revocation Oder Wiederruffungs Schrieff: Welche bestehet in erklerung des schönen Spruchs des H. Apostels Petri/ in seiner Ersten Epistel am Ersten Capitel: fürnemblich auf Widerlegung des Bapstumbs gerichtet; Derohalben an das offentliche tage Liecht gegeben/ damit alle Evangelische Lutherische Christen inn ihrem rechten Glauben gesterckt/ und befestiget ... werden (Olsse: Bössemesser, 1611), USTC 2106978.

37 Jens Bruning and Ulrike Gleixner (eds.), Das Athen der Welfen - Die Reformuniversität Helmstedt 1576-1810 (Wiesbaden: Harrassowitz, 2010).

38 Johann Ulrich von Baumgarten, Kurtze Revocation Schrifft (Bremen: Herman Brauer, 1686).

39 Schunka, Gäste, die bleiben, pp. 322-336. 
them more authentic for their listeners and readers. This process led to some interesting variations in the revocation sermons, which the next part of this chapter focuses on.

\section{Adapting the Revocation Sermon}

Solely focusing on the shared features of the revocation sermon and portraying them as uniform would be too simplistic a characterisation. As with any genre, there were also significant variations in the revocation sermons, leading to opportunities to expand our understanding of conversions significantly. Most importantly, they were always, to a greater or lesser extent, autobiographical. While funeral sermons contain biographies of the deceased written by other people, in revocation sermons the authors had the opportunity to portray themselves as they pleased, providing a unique opportunity to justify their own beliefs.

Many of the sermons followed rhetorical strategies and employed shared tropes, but they could also draw on personal experiences. Some of the converts described specific experiences they had during their conversion process, for example that they were tempted into becoming a monk by a scheming abbot. In some of the accounts, parents contributed to the Catholicism of their children and encouraged them to join a monastery, while in others parents did not want their children to become a member of the order. ${ }^{40}$ Ultimately, the converts came to see the error of their ways, many of them claiming that they had doubts for many years before eventually leaving the monastery.

The general outline of these conversion narratives is the same in most of the revocation sermons, but a closer analysis of the details and language used reveals that they contained personalised elements, and that not all sermons followed the same patterns. Even the structure could be altered depending on the preferences of the converts or their printers. Johannes Samson, for example, expanded his revocation into three sermons, which were bound together into a more than 10o-page book in quarto format. ${ }^{41}$ Johann Ludwig Niclaßi's revocation sermon was bound together with his funeral sermon, including an image of the deceased man. ${ }^{42}$ Even in the title of the funeral sermon, readers

40 Rabe, Christliche Revocation Predigt, preface; Fridericus Tancklerus, Exultans David, Seu anima fidelis ob de ictum Anti Christianum Goliathum triumphans. Kurtze RevocationsPredigt, Welche Fridericus Tancklerus In dem Kloster Grossen Bürlo in Stifft Münster 12. Jahr gewesener Bernhardiner Mönch ... (Lüneburg: Heinrich Jakob Kelp, 1703), preface.

41 Samson, Illuminatus Samson.

42 Niclaßi, Wohlverdientes Ehren-Gedächtnüs. 
were reminded that Niclaßi used to be a Roman Catholic abbot, showing how important the conversion was in a person's biography.

A defining feature of Ludwig Augustus von Maccors' revocation sermon was marital and familial language. Maccors gave his sermon in 1729 in the main church of Wolfenbüttel. He described himself as a man who had wandered around like a bride left by her bridegroom, 'miserably and pitifully, poor, blind and bare'43 But now he was married to Christ and, like a bride, he had to fulfill certain responsibilities. One of them was to wear a white dress, a symbol of innocence, which was then contrasted with Christ's red blood. Papists could not marry Christ because they relied on human, not divine, commands, making them into the Babylonian whore. ${ }^{44}$ Directed at his readers and listener, he wrote 'You shall be the bride of Jesus, the divine bridegroom. ${ }^{45}$ Maccors constructed his sermon idiosyncratically, likening himself to a woman and praying for Jesus to keep him as his bride. Moreover, compared to other sermons, Maccors emphasised that he converted on a specific day.

Martin Schimschalck, a Hungarian nobleman, gave his revocation sermon in Regensburg in 1654. His sermon was printed in Latin and translated into German in 1658 . His vocabulary was more influenced by martial language. The Word of God had 'pierced his heart like a sword', and he approached a critique of Catholicism like a wood worker, felling a tree. He had to 'beat at' the root and stem. ${ }^{46} \mathrm{He}$ wrote further that, like a sailor, he had to reach the safe port of the Bible. ${ }^{47}$ The Papists, on the other hand, were associated with domestic labour. Mockingly, Schimschalck wrote that they stoked purgatory 'in the Roman kitchens. ${ }^{48}$ This kind of gendered argument was diametrically opposed to Maccors' account, where the convert took on the feminised role of a bride.

A third revocation sermon revolved around yet another set of concepts. Walter Averdunck's revocation sermon from 1634 is notable for its imaginative language. He had been a Capuchin in Westphalia for nineteen years, and converted publicly in Frankfurt am Main. Although Averdunck also used biblical reference points, he tapped into popular stories, turns of phrases and

43 Ludwig A. von Maccors, Die Liebreiche Vermählung Christi mit uns: Zum öffentlichen Zeugniß der göttlichen Liebe ... Jn einer Revocations-Predigt ... Jn der Haupt-Kirche B.M.V. zu Wolffenbüttel Dominica XX Trinit. Anno 1729. aus dem ordentlichen Evangelio vorgetragen (Wolfenbütel: Christian Bartsch, 1729), p. 2: 'eine von ihrem Brautigam verlassene Braut elend und jämmerlich / arm / blind und bloß’. von Maccors, Die Liebreiche Vermählung Christi, p. 13.

45 von Maccors, Die Liebreiche Vermählung Christi, p. 14.

46 Schimschalck, Kurtze Revocations Predigt, [p. 2].

47 Schimschalck, Kurtze Revocations Predigt, [p. 5].

48 Schimschalck, Kurtze Revocations Predigt, [pp. 5/6]. 
other kinds of narratives. When he became Catholic, he described himself as a bird or a fish, who sees a kernel or worm and 'hopes to find life in it, but instead finds death because it does not see the rope or fish hook. ${ }^{49}$ The Devil tempted him like 'a smart apothecary' who covered the 'poison with gold and white sugar ... so that everyone had a great desire and appetite for it. ${ }^{50}$ In a similar way, Catholics over-sugared their ceremonies so that for many years, Averdunck did not notice. Like ostriches, who appeared to be birds but could not fly, so the monks seemed to be pious, though they were actually sinful. ${ }^{51}$ Many of them went to the Pope, like 'flies and insects to a big heap'.52 Like a salmon that moves into new water, he eventually hoped to leave the salty water that represented the monastic life. ${ }^{53}$ His sermon was steeped in these kinds of comparisons and, although the general outline of the conversion is similar to many others, his language is distinctive.

\section{Conclusion: The Decline of the Revocation Sermon}

Conversions were connected to a range of actors who supported and promoted them, but could also challenge and ridicule them. From the early seventeenth century onwards, when Lutheranism had a distinctive shape, men and women converted to that faith. These conversions were rarely as spectacular as those by Catholics in the New World, which orders wrote about in their

49 Walter Averdunck, Revocations Predigt Jn hochansehlichster Gegenwart Jhr Excellentz Herrn ReichsCantzlers / auch Fürsten / Grafen und Herren / und abgeordneten Legaten (Franckfurt am Mayn: Anton Hummen, MDCXXXIV[1634]), USTC 2035245, p. 3: 'wie den Vögeln und den Fischen: wann die etwa ein Körnlein oder Würmlein sehen / so hoffen sie darinnen ihr Leben zu finden / finden aber den Todt / diweil siedes Garns und Angels nicht warnemen'.

Averdunck, Revocations Predigt, p. 4, 'der Teuffel gehandelt / wie ein kluger Apotheker / der auswendig das Gifft mir Gold und Zuckerweis dermassen lieblich und anmütig zu machen / das jederman darzu lust / und appetit hat'.

$5^{1} \quad$ Averdunck, Revocations Predigt, p. 6.

52 Averdunck, Revocations Predigt, p. 12.

53 Averdunck, Revocations Predigt, p. 4: 'Man liset von den Salmen / wann sie einmal aus dem Meer / und gesaltzenem Wasser in den Rhein und andere süsse Wasser kommen / das sie darinnen so grossen Luft und Süssigkeit empfinden / das sie von dannen nimmermehr begehren heraus zu kommen. Als ich gedachte in den Capuciner Orden zu treten / verhoffte ich aus der Welt / als aus einem trüben gesaltzenen Meer zu frischen Wassern / und Heilbrunnen Israels zu gelangen / da die Brüder einträchtiglich beyeinander wohnen: Da habe ich lauter Bitterkeit unnd Haderwasser / das ist / Feindschafft / Zorn / Zanck / Zwitracht / Neid / Has / Mord / und dergleichen Werck des Fleishces: also einwütent und wallendes Meer gesehen[n] / dessen Wellen jm[m]er schändlichen unstat auswerfen'. 
letters and travel accounts. But they nonetheless formed an important part of early modern Lutheranism, as they enabled theologians to show the power of Lutheranism against 'popery'. The active promotion of conversions shows that Lutherans wanted to convert Catholics and the available financial and logistical support suggests that this was an active effort by Lutheran theologians and princes.

By the middle of the eighteenth century, there were no more revocation sermons. It is likely that conversions had become less contentious by the eighteenth century. In the sixteenth and seventeenth centuries, conversions were a major victory for the confession that a convert had recently joined. However, by the eighteenth century, the religious and political climate had changed. Now, new religious developments were on the rise and the Enlightenment had taken a more thorough hold of large parts of early modern Europe. Another reason for the decline of the revocation sermon was the inherent limitations of the genre. The fact that the revocations were performed as a sermon also meant that lay converts and women could not express themselves in this way. ${ }^{54}$ Revocation sermons were not an adaptable genre, having a limited number of potential authors.

The changing political and religious dynamics of the eighteenth century also resulted in other ways of expressing conversion narratives, including new rhetorical tropes not suitable to be expressed in a sermon, but also different genres of writing. With new types of media, conversion narratives could be portrayed differently, for instance through autobiographical writings or longer accounts of personal journeys of discovery. While these genres also existed in earlier periods, the increased popularity of these other genres led to the decline of the revocation sermon.

At the same time, political actors and clerics no longer benefitted from the promotion of the revocation sermon in the same manner, as different priorities came to the fore in the eighteenth century. Just as the funeral sermon declined over the course of the early modern period, so did the revocation sermons, and this was partly linked to shifting political and religious landscapes, which influenced princes, dukes and important clerics, who found other ways of promoting conversions and expressing themselves.

54 For example, Martha Elisabeth Zitter, Gründliche Ursachen/ welche Jungfer Marthen Elisabeth Zitterinn bewogen/ das Frantzösische alias Weiß-Frauen Kloster in Erffurt/ Ursuliner Ordens/zuverlassen/ und sich zu der waaren Evangelischen Religion zu bekennen : In einen Schreiben an ihre Mutter (Tit.) Frau Maria Margaretha jetzo (Tit.) Herrn Johann Hübners von Rosenberg/Obr-Leutenants/ und Fürstl. Bamberg. Commendantens in Cronach Eheliebste/ Angezeiget (Jena: s.n., 1678). 
This is not to say that, in the eighteenth century, some kind of Enlightenment religious toleration necessarily led to more religious peace. Rather, the disappearance of the printed revocation sermons might indicate that religious conflict had moved to other genres. As Benjamin Kaplan and others have argued, the notion of the rise of religious toleration in the eighteenth century cannot be applied universally. ${ }^{55}$ Indeed, the revocation sermons show that religious conflicts continued long after the Thirty Years War. But more research is needed to determine why revocation sermons were only delivered for around 130 years.

The printed revocation sermons show how a group of individuals used print to further their cause. In delivering and printing the sermons, the converts showed themselves as loyal Lutherans, who converted for the right reasons and had no intention of reverting to their Catholic beliefs. They openly attacked Catholic doctrine and practices, using their status as eyewitnesses to criticise Catholicism. At the same time, the sermons allowed for individual adaptations, especially in the language that the converts used. Printers could hope for a profit on a text that fit into the well-established format of the sermon, yet had more polemical potential than many ordinary sermons. Creating and using this genre of Lutheran writing gave the converts the opportunity to justify themselves not only to the people who listened to their sermon, but to a wider public.

55 Benjamin J. Kaplan, Divided by Faith: Religious Conflict and the Practice of Toleration in Early Modern Europe (Cambridge: Belknap Press, 2007), especially pp. 340-356. 